\title{
MENIMBANG GAGASAN PERUBAHAN KONSTITUSI DAN TATA CARA PERUBAHAN KONSTITUSI REPUBLIK INDONESIA 1945
}

\author{
THE IDEA TO AMEND OF INDONESIA CONSTITUTION AND ITS \\ MECHANISM
}

\author{
"Muh.Risnain \& "Sri Karyati \\ Universitas Mataram dan Unversitas Islam Al-Azhar Mataram \\ Email : risnain82@gmail.com; ukhti_bgt@yahoo.com \\ Naskah diterima : 21/03/2017; revisi : 25/03/2017; disetujui : 27/04/2017
}

\begin{abstract}
The idea to amend the constitution of republic of Indonesia is constitutionally, academically, an inline with developing of the society. This idea can be realized while supporting by political and social condition. The idea to repositioning MPR as highest state body faced constitutionally restrain by change of president election by the people directly. Several substance will be proposed to be amend related to, state, state commission, and monopoly right of state in natural resources. The mechanism to amend constitution through referendum process and constitutional process in MPR.
\end{abstract}

Keywords: Amendement, Constitution and Idea.

Abstrak

\begin{abstract}
Gagasan perubahan UUD NRI 1945 merupakan gagasan yang konstitusional, akademis, sesuai dengan pengalaman sejarah yang berkembang sesuai dengan perkembangan kehidupan masyarakat. Gagasan itu akan dapat terwujud manakala didahului oleh situasi sosial dan politik yang mendukungnya. Gagasan untuk repositioning MPR sebagai lembaga tertinggi negara menghadapi hambatan konstitusional karena perubahan sistem pemilihan presiden dari pemilihan oleh MPR menjadi pemilihan langsung oleh rakyat, ketiga, beberapa usulan substansi perubahan UUD berkaitan dengan, wilayah negara pasal (25 A), komisi negara (pasal 30) dan pasal 33 (hak penguasaan negara), dan, mekanisme perubahan dilakukan melalui referendum terlebih dahulu yang diikuti oleh proses konstitusional di MPR.
\end{abstract}

Kata Kunci : Amandemen, Konstitusi dan Gagasan

\section{PENDAHULUAN}

Kostitusi sebuah negara merupakan kulminasi dari shared value yang diyakini bersama sebuahbangsauntuk mengorganisir negara sesuai dengan kondisi sosial dan politik yang hidup dan berkembang dalam masyarakat ${ }^{1}$. Konstitusi di sebuah negara tidak dibangun di ruang hampa, tetapi lahir dari kondisi sosial dan politik masyarakat yang menyelimutinya kemudian menjadi

\footnotetext{
${ }^{1}$ Mochtar Kusumaatmadja dan Arief Sidharta, Pengantar Ilmu Hukum, Alumni, bandung, 2000, hlm. 10
}

kesepakatan bersama yang dituangkan dalam konstitusi. Pembentukan dan perubahan konstitusi pun merupakan kulminasi kondisi sosial dan politik sebuah negara $^{2}$. Gagasan perubahan konstitusi sebuah negara pun merupakan sebuah hal yang normal tidak terlalu istimewa dalam kehidupan ketatanegaraan ${ }^{3}$. Hal yang lazim dalam perubahan konstitusi adalah adanya

\footnotetext{
${ }^{2}$ Satjipto Rahardjo, Ilmu Hukum, (Bandung : Citra Aditya, 2000), hlm. 206

${ }^{3}$ K.C.Wherare, Modern Constitustions, Oxford university Press, UK, 1996, hlm. 5
} 
peristiwa sosial dan politik ketatanegaraan yang drastis, misalnya saja pada tahun 1998 terjadinya demonstrasi mahasiswa hampir di seluruh Indonesia yang berakhir dengan lengsernya almarhum mantan presiden Soeharto merupakan trigger bagi tuntutan perubahan terhadap Undang-Undang Dasar Negara 1945. Indonesia pun melakukan perubahan UUD 1945 sejak tahun 1999 hingga 2002.

Empat belas tahun setelah perubahan UUD NRI 1945 dilakukan ternyata membawa implikasi yang luar biasa terhadap penyelenggaraan kehidupan berbangsa dan bernegara. Harapan perubahan UUD NRI 1945 yang akan memperbaiki sistem kehidupan berbangsa dan bernegara ternyata tidak seindah yang diharapkan publik. Banyak pihak kemudian mengemukakan gagasan menghendaki agar dilakukan perubahan terhadap UUD NRI $1945^{4}$. Menurut Badan Pengkajian MPR gagasan penataan sistem ketatanegaraan melalui perubahan UUD NRI 1945 terbelah menjadi tiga pandangan, pertama, pandangan yang menghendaki perlunya penataan sistem ketatanegaraan Indonesia melalui perubahan kelima UUD NRI 1945. Kedua, pandangan yang menghendaki sistem ketatanegaraan Indonesia kembali kepada UUD NRI yang asli sebelum dilakukan perubahan, dan ketiga, pandangan yang menyatakan bahwa sistem ketatanegaraan yang ada saat ini sudah sesuai dengan kebutuhan dan perkembangan masyarakat, tinggal bagaimana mengimplementasikan UUD NRI 1945 dalam kehidupan nyata berbangsa dan bernegara.Perdebatan perubahan UUD NRI 1945 hingga kini terus berlangsung baik pada perdebatan akademis maupun pada ranah sosial dan politik. Wilayah perdebatan berkisar pada persoalan tingkat urgensitas perubahan UUD 1945 ? materi apa saja yang diubah ? dan bagaimana mekanisme dan prosedur perubahan UUD

\footnotetext{
${ }^{4} \mathrm{Ni}$,matul Huda, Politik ketatanegaraan Indonesia : kajian terhadap dinamika perubahan UUD 1945, (Yogyakarta : FH UII, 2002,) hlm. 49.
}

1945? Ketiga pertanyaan tersebut memerlukan jawaban bukan saja bermaksud menjawab masalah hasrat akademik,tetapi jawaban terhadap kebutuhan nyata masyarakat.

Artikel ini bermaksud menjawab tiga masalah besar itu yang kemudian diuraikan dalam beberapa sub pokok pertanyaan untuk menemukan jawaban akademis terkait mekanisme dan prosedur perubahan UUD NRI 1945.

\section{A.Perubahan UUD 1945 : Perlukah ?}

Menurut K.C Wherae konstitusi merupakan keseluruhan sistem ketatanegaraan suatu negara, kumpulan peraturan-peraturan yang mendasar dan mengatur atau mengarahkan pemerintahan. Peraturanperaturan tersebut ada yang dimaknai hukum dan terdapat juga norma yang bersifat non-hukum. Konstitusi adalah resultan dari berbagai kekuatan politik, ekonomi, dan sosial yang berjalan pada waktu pembentukkannya. Dalam buku yang sama K.C. Wherae mengatakan terdapat beberapa metode perubahan konstitusi, yaitu : pertama, perubahan formal (amandemen formal), kedua, perubahan melalui penafsiran yudisial, dan ketiga, kebiasaan dan tradisi (konvensi ketatanegaraan).

Perubahan konstitusi sebuah negara bukanlah sebuah hal yang tabu dilakukan. Peristiwa ini hampir dilakukan oleh semua negara, karena sesungguhnya konstitusi bukanlah sebuah kitab suci yang selalu harus "disakralkan" dan tidak boleh disentuh untuk diubah. Indonesia sesungguhnya punya pengalaman yang panjang bagaimana konstitusi diubah dan diganti kemudian pernah juga disakralkan sebagai kitab suci keramat ${ }^{5}$.

Secara periodik perkembangan konstitusi Indonesia dibagi dalam beberapa peri-

${ }^{5}$ Saldi Isra, Kekuasaan dan Perilaku Korupsi : catatan Hukum, (Jakarta : Kompas Media Nusantara, 2009), hlm. 48. 
ode $^{6}$ : konstitusi pertama, periode 18 agustus 1945-27 desember 1949. Disahkan pada 18 agustus 1945 oleh panitia persiapan kemerdekaan Indonesia (PPKI), ketuanya, Ir. Soekarno, wakilnya Dr. M.Hatta. Nashkah UUD disiapkan BPUPKI utk persiapan kemerdekaan Indonesia. UUD yg disahkan PPKI dianggap sah karena merupakan hasil dari revolusi bangsa Indonesia utk merdeka dari penjajah. UUD bersifat sementara karena UUD yang tetap akan disahkan MPR. Konstitusi kedua: Merupakan UUD RIS 27 desember 1949 sampai dengan 17 agustus 1950.Konstitusi dihasilkan dari keinginan belanda utk berkuasa kembali di Indonesia melalui agresi militer I (1947) dan II (1948).Diadakan konferensi meja bundar di bawah PBB utk membahasa masalah Indonesia. menghasilkan tiga persetujuan pokok : (1). Mendirikan Republik Indonesia Serikat, (2). Penyerahan kedaulatan kepada RIS, (3). Didirikan negara uni antara RI dan kerajaan Belanda. Dibuat naskah UUD antara wakil RI (KNP) dan delegasi BFO. Konstitusi ini disetujui 14 desember 1949. Sejak 1950 tersusunlah naskah UUD RIS. Dengan berdirinya RIS maka RI tetap ada dan menjadi salah satu negara bagian dari RIS sama seperti Negara Indonesia Timur, negara pasundan, negara sumatera timur, negara jawa timur, dsb. UUD 1945 hanya berlaku dalam wilayah RI saja, diluar itu berlaku konstitusi RIS. Konstitusi RIS hanya bersifat sementara ${ }^{7}$.

Konstitusi ketiga : UUDS 1950. dibentuk utk menyatukan kembali bentuk negara kesatuan republik Indonesia karena RIS tidak bertahan lama.Naskah UUDS disahkan oleh BP KNP, DPR dan senat RIS pd 14 agustus 1950 dan mulai berlaku 27 agustus 1950. UUD 1950 merupakan perubahan atas UUD RIS melalui Psl 190, psl 127 (a) dan Pasal 191 mengatur tentang prosedur perubahan UUD RIS.

\footnotetext{
${ }^{6}$ Jimly Asshiddiqie, Pengantar Ilmu Hukum Tata Negara, (Jakarta : Sekjen MK RI,2006) hlm.34.

${ }^{7}$ Jimly Assidiqie, Perihal Undang-Undang, (Jakarta : Konstitusi Press, 2006), hlm. 50.
}

Konstitusi keempat : kembali ke UUD 1945 ( 5 juli 1959-19 oktober 1999).Situasi politik pasca pemilu 1955 utk memilih anggota konstituante tidak kondusif karena konstituante tidak dapat bersidang sebagamana mestinya Konstituante tidak berhasil merumuskan UUD yang tetap utk menggantikan UUDS 1950.Presiden Soekarno mengambil kebijakan mengeluarkan Dekrit Presiden melalui Kepres pada tanggal 5 juli $1959 .{ }^{8}$ Dekrit presiden tersebut dapat diterima dan konstitusional sebagai keadaan yang bersifat staatsnoodrecht (hukum tata negara darurat).

Sejak Dekrit presiden 5 juli 1959 naskah UUD 1945 berlaku kembali konstitusi RI dan sebagai hukum tertinggi yang berlaku di NKRI. UUD 1945 masih tetap bersifat sementara dan kepada MPR diberi tugas kewenangan untuk menetapkan UUD 1945. Namun MPR sejak 1977-1997 tidak pernah melakukan tugasnya (sakralisasi UUD 1945.UUD 1945 disamping memiliki naskah pokok (batang tubuh) juga memiliki penjelasan. Menjadi perdebatan apakah penjelasan mrpkan bagian dri UUD 1945 atau tidak dan menjadi interpretasi autentik dari UUD 1945.Banyak materi muatan penjelasan UUD yang bertentangan dengan batang tubuh, misalnya. Istilah presiden sebagai kepala negara dan kepala pemerintahan dalm sistem presidensil, tetapi dalm praktek menjadi sistem pemerintahn parlementer, termasuk juga sidang istimewa ${ }^{9}$.

Konstitusi kelima, konstitusi Peralihan (19 oktober 1999-10 agustus 2002). Terjadi karena gerakan reformasi nasional yg dipelopori mahasiswa yg menghendaki perbaikan dalam penyelenggaraan negara dari orba ke orde reformasi. Periode ini

\footnotetext{
${ }^{8}$ Isi dekrit presiden 5 juli $1959:$ 1). membubarkan konstituante, (2).memberlakukan kembali UUD 1945 di seluruh wilayah NKRI dan tidak berlakunya UUDS 1950, dan (3).pembentukan MPRS sementara.

${ }_{9}$ Maria Farida S, Ilmu Perundang-undangan : Jenis, Fungsi dan Materi Muatan,(Yogyakarta : Kanisius, 2007), hlm.2.
} 
merupakan peralihan konstitusi dari UUD 1945 hasil dekrit presiden 1959 menjadi UUD 1945 pasca perubahan yg menuangkan aspirasi reformasi ketetanegaraan ( transitional constitution). Perubahan dilakukan empat kali, 1999, 2000, 2001 dan 2002. Dilakukan oleh MPR yg mengalami evolusi kedudukan dari superpower menjadi lembaga negara powerless.

Konstitusi keenam,Konstitusi pasca perubahan UUD 1945(10 agustus-sekarang). Reformasi konstitusi telah selesai dilakukan dengan disahkannya perubahan keempat pada 10 agustus 2002. Perubahan dilakukan oleh Badan pekerja MPR (BP MPR) dan membentuk panitia ad hoc (Pah I, II dan III). Menghasilkan 174 substansi baru atau $300 \%$ dari isi UUD sebelumnya.

Pengalaman berkonstitusi kita di atas menunjukkan bahwa konstitusi mengalami dinamika sesuai dengan situasi sosial dan politik. Pertanyaanya apakah gagasan perubahan UUD NRI 1945 yang telah disahkan padatahun2002 memilikilandasan sosial,politik,hukum yang mendekati kondisi ketika terjadi perubahan konstitusi di atas. Penulis dapat memastikan bahwa kondisi kehidupan ketatanegaraan saat ini masih aman dan kita mulai menata sistem kehidupan ketatanegaraan kea rah yang lebih stabil. Masa transisi konstitusi telah kita lewati selama kurang lebih 14 tahun, dinamika ketatanegaraan masih berada pada situasi yang tidak segenting situasi pada perubahan-perubahan konstitusi yang telah kita lewati ${ }^{10}$.

Namun demikian bahwa gagasan perubahan konstitusi bukanlah hal yang tabu dibicarakan di forum akademik maupun forum politik. Bukan zamannya lagi kita menganggap bahwa UUD NRI 1945 adalah kitab suci yang disakralkan. Zaman terus berubah, pergaulan internasional juga terus berubah,konstitusi harus mengikuti

\footnotetext{
${ }_{10}$ Moh.Mahfud M.D, Membangun Politik Hukum, Menegakkan Konstitusi (Jakarta : Pustaka LP3ES , 2006) hlm.5.
}

perkembangan sosial dan politik yang selalu dinamis. Perubahan konstitusi adalah hal yang jamak saja dilakukan, tinggal menunggu moment dan situasi yang tepat untuk melakukan perubahan ${ }^{11}$.

\section{B. Reposisi MPR sebagai Lembaga ter- tinggi negara, mungkinkah ?}

Harus diakui bahwa MPR merupakan lembaga negara genuine Indonesia yang lahir sesuai dengan struktur masyarakat Indonesia yang kental dengan suasana bermusyawarah. Lembaga negara yang lain seperti presiden, BPK, MA, MA kepolisian, kejaksaan, merupakan lembaga "warisan"belanda atau kita adopsi dari praktek negara lain. Maka pada UUD 1945 yang belum diamandemen MPR ditempatkan sebagai lembaga tinggi negara dengan kewenangannya yang superpower. Pasca perubahan UUD 1945 baik kelembagaan, pengisian jabatan, maupun kewenangan MPR berubah secara drastis, sehingga banyak pihak "bernostalgia" hendak menempatkan kembali MPR sebagai lembaga negara "produk lokal" Indonesia ${ }^{12}$.

Berdasarkan pasal 2 ayat (1) UUD NRI 1945 keanggotaan MPR teridiri atas anggota Dewan Perwakilan Rakyat dan anggota Dewan Perwakilan Daerah yang dipilih melalui pemilihan umum. Ada dua hal penting dalam pasal 2 ayat (1) di atas, pertama, keanggotaan MPR bukan mewakili kelembagaan DPR dan DPD, tetapi merupakan keanggotaan perorangan. MPR merupakan joint session saja untuk melakukan sidangsidang dalam menjalankan kewenangan konstitusionalnya. Artinya MPR itu ada dan melaksanakan kewenangannya ketika dia bersidang mengubah atau menetapkan UUD 1945, melantik Presiden dan/atau

${ }^{11}$ Satya Arinanto,Politik Pembangunan Hukum Nasional dalam Era Pasca reformasi, Jurnal Konstitusi Volume 3 Nomor 3 September 2006, (2006), hlm.79.

${ }^{12}$ Mochtar Kusumaatmadja, Konsep-Konsep Hukum dalam Pembangunan : Kumpulan Karya Tulis Prof.Dr. Mochtar Kusumaatmadja, SH.,LL.M (Bandung: Alumni, 2002), hlm.3-4. 
wakil presiden, dan memberhentikan Presiden dan/atau Wakil Presiden dalam masa jabatannya menurut Undang-Undang Dasar dalam rangkaian akhir proses impeachment. Kedua, pengisian jabatan MPR.Jika sebelumnya yang menjadi anggota MPR terdiri anggota parpol, golongan karya, ABRI, Utusan daerah dan utusan golongan yang tidak semuanya dipilih melalui pemilu. Hanya anggota DPR yang dipilih melalui pemilu, sedangkan golongan karya, ABRI, Utusan daerah dan utusan golongan tidak dipilih tetapi ditunjuk.Pada perubahan UUD 1945 anggota MPR terdiri dari anggota DPR dan DPD yang dipilih melalui pemilu. Tidak ada lagi anggota MPR yang mendapatkan kursi "gratis", semuanya harus berkompetisi untuk menjadi anggota DPR atau anggota DPD. Menurut penulis pengisian jabatan publik yang mewakili kepentingan rakyat memang harus dilakukan dengan cara pemilihan langsung oleh rakyat, bukan melalui penunjukkan (appointed) yang didasarkan pada pertimbangan interest politic yang sama dan cenderung subyektif untuk melanggengkan kekuasaan. Mereka yang tidak terakomodir dalam kekuatan politik seperti utusan golongan, ABRI maupun Utusan daerah dapat memilih jalur menjadi anggota DPD untuk memperjuangkan aspirasinya atau menjadi anggota parpol kemudian menjadi anggota DPR.

Persoalan yang tidak kalah pentingnya yang menjadi perdebatan akademik dan politik adalah kedudukan MPR yang sejajar dengan lembaga negara lainnya. MPR tidak lagi sebagai lembaga tertinggi negara, tetapi lembaga tinggi negara yang sama kedudukannya sama dengan DPR, DPD, Presiden, MA, MK, dan BPK. Implikasinya segala kewenangan yang dimiliki MPR berdasarkan UUD 1945 yang belum diubah tidak dapat dipertahankan lagi seperti menetapkan GBHN, menjadi Mandan Presiden. Praktis MPR hanya memiliki tiga kewenangan di atas. Lalu apakah perlu mengembalikan kedudukan dan kewenangan MPR seperti dulu sebelum UUD 1945 diubah ? Menurut penulis pilihan kebijakan ini memang sangat dilematis karena berimplikasi pada sistem kehidupan ketatanegaraan yang signifikan. Jika MPR dikembalikan pada posisi yang dulu maka berimplikasi pada pemilihan presiden. MPR versi UUD 1945 yang lalu memiliki kewenangan menetapkan GBHN dan menjadi Mandan Presiden karena MPR memiliki kewenangan memilih presiden. Sekarang ini terjadi perubahan besar dalam kehidupan demokrasi kita rakyat menghendaki agar semua pejabat publik mulai kepala desa sampai presiden dipilih secara langsung. Karena presiden dipilih secara langsung bukan oleh MPR lagi maka presiden tidak lagi sebagai mandataris MPR dan harus menjalankan GBHN yang ditetapkan MPR.

Keadaaan sebaliknya jika pilihan politik kita adalah untuk meloncat ke belakang secara drastis kembali kepada UUD 1945 sebelum diamandemen. Maka MPR dapat diposisikan sebagai lembaga negara genuine Indonesia dengan segala kewenangannya. Tetapi pilihan ini membutuhkan social cost and political cost yang mahal, sama mahal dan rumitnya ketika pilihan untuk mengubah UUD 1945 pada masa awal reformasi.

\section{Beberapa substansi usulan perubahan UUD NRI 1945.}

Penulis tetapberpendirian bahwa gagasan perubahan UUD NRI 1945 bukanlah sesuatu hal yang tabu dan imposibble dilakukan pada era demokrasi sebagaimana dipraktekan ketika UUD 1945 disakralkan rezim orde baru dulu. Gagasan akademis maupun politis untuk mengubah UUD NRI 1945 tetap konstitusional sepanjang dilakukan dengan cara-cara konstitusional dan sesuai dengan perkembangan kehidupan sosial dan politik. Walaupun menurut penulis perkembangan sosial dan politik saat ini 
"Muh. Risnain dan "Sri Karyati|Menimbang Gagasan Perubahan Konstitusi Dan Tata Cara.......

agak susah untuk melakukan perubahan UUD NRI 1945.

Pada tahun 2011 yang lalu kelompok DPD di MPR pernah meluncurkan Naskah resmi perubahan kelima UUD NRI 1945 yang disertai perubahan pasal beserta alasnnya. Menurut penulis sebagian besar usulan perubahan yang diajukan tersebut lebih banyak pada aspirasi pengkuatan posisi dan kewenangan DPD dalam sistem ketatanegaraan. Walaupun demikian ada beberapa hal yang menurut penulis sepaham dengan usulan DPD.

Walaupun demikian jika seandainya dilakukan perubahan maka ada beberapa hal yang patut didiskusikan untuk diubah dan ditambah.

1. Wilayah Negara.

Pasal 25 A UUD NRI 1945 yang semulateridiridarisatupasaldanberbunyi "Negara Kesatuan Republik Indonesia adalah sebuah negara kepulauan yang berciri Nusantara dengan wilayah yang batas-batas dan hak-haknya ditetapkan dengan undang-undang"

Penulis mengusulkan untuk diubah menjadi di dua ayat dengan redaksi dan susunan sebagai berikut :

Pasal 25 A

1) Wilayah Negara Kesatuan Republik Indonesia adalah wilayah dimana negara memiliki kedaulatan, hak-hak berdaulat, baik wilayah darat, laut dan ruang udara.

2) Negara Kesatuan Republik Indonesia adalah sebuah negara kepulauan yang berciri Nusantara dengan wilayah yang batas-batas dan hak-haknya ditetapkan dengan undang-undang.

2. Komisi Negara (penambahan bab baru diantara Bab XII pertahanan dan keamanannegaradanBabXIIIpendidikan
dankebudayaanmenjadiBABXIIAKomisi Negara).

Gagasan untuk memasukan bab tentang komisi negara penulis sadur dari usulan perubahan yang diajukan kelompok DPD di MPR pada tahun 2011.

PengaturankomisinegaradalamUUD NRI1945 digagas dalamrangkapenguatan prinsip negara hukum yang tertuang pada pasal2ayat(1)UUDNRI1945.Keberadaan komisi negara untuk mendorong dan menjaga 1). Sistem peradilan yang independen dan berintegritas, bersih dari mafia peradilan maka komisi yudisial diatur dalam bab tersendiri keluar dari pasal24UUD NRI 1945.2). Perlindungan HAMmakadiakomodir KomnasHAM,3). PemilihanumumdibentukKPUdalambab tersendiri, dan terciptanya pemerintahan yang baik dan bersih maka dibentuklah KPK.

\section{Pasal 30 B}

Untuk mengkuatkan prinsip negara hukumdibentukKomisipemilihanumum, komisi pemberantasan korupsi, komisi yudisial, komnas HAM yang bersifat mandiri.

3. Perekonomian nasional

Penulis menngusulkan agar pasal 33 ayat (2) UUD NRI 1945 diubah dari,

"(3) Bumi, air dan kekayaan alam yang terkandung di dalamnya dikuasai oleh negara dan dipergunakan untuk sebesar besar kemakmuran rakyat.

Menjadi”

"(3) seluruh kekayaan alam yang terkandung dalam wilayah kedaulatan, hak-hak berdaulat, baik di darat, di laut, maupun ruang udara dikuasi oleh negara dan dipergunakan untuk sebesar-besarnya kemakmuran rakyat."

"(4). Penguasaan negara dilakukan me- 
lalui perumusan kebijakan, pengurusan, pengaturan, pengelolaan, dan pengawasan guna ketersediaan yang cukup dandistribusi yang adil serta terjangkau untuk sebesar-besarnya kemakmuran rakyat."

4. Konsensus dasar Perubahan UUD NRI 1945.

Pada tahun 2000 dicapai kesepakatan dasar untuk tidak melakukan perubahan terhadap hal-hal sebagai berikut ;

- Tidak mengubah pembukaan UUD 1945

- Tetap mempertahankan NKRI

- Mempertegas sistem presidensil

- Penjelasan ditiadakan serta hal2 normati dalam penjelasan dimasukan dalam Pasal-pasal.

- Perubahan dilakukan secara adendum.

\section{Mekanisme Perubahan UUD NRI 1945 : Perlukan diubah ?}

Mekanisme perubahan UUD NRI 1945 dalam pasal 37 UUD NRI 1945 didesain dengan beberapa kekhususan. yaitu, kelembagaan, subyek yang mengubah, bentuk usulan, dan mekanisme pengambilan keputusan untuk perubahan.

1) Usul perubahan pasal pasal UndangUndang Dasar dapat diagendakan dalam sidang Majelis Permusyawaratan Rakyat apabila diajukan oleh sekurang kurangnya 1/3darijumlahanggotaMajelis Permusyawaratan Rakyat. ****).

2) Setiap usul perubahan pasal-pasal UndangUndang Dasar diajukan secara tertulis dan ditunjukkan dengan jelas bagian yang diusulkan untuk diubah beserta alasannya. ${ }^{* * * *}$ )

3) Untuk mengubah pasal-pasal UndangUndang Dasar, sidang Majelis Permusyawaratan Rakyat dihadiri sekurang-
kurangnya2/3darijumlahanggotaMajelis Permusyawaratan Rakyat. ${ }^{* * *}$ )

4) Putusan untuk mengubah pasal-pasal Undang-Undang Dasar dilakukan dengan persetujuan sekurangkurangnya limapuluh persen ditambah satu anggota dari seluruh anggota Majelis Permusyawaratan Rakyat. ${ }^{* * * *}$ )

5) KhususmengenaibentuknegaraKesatuan Republik Indonesia tidak dapat dilakukan perubahan.

Hal menarik untuk didiskusikan adalah gagasan perubahan UUD 1945 cukup berawal dari 1/3 anggota MPR atau berasal dari aspirasi masyarakat. Menurut penulis bahwa perubahan UUD NRI 1945 sebagai hukum tertulis yang tinggi dalam penyelenggaraan kehidupan ketatanegaraan dapat dilakukan dengan menanyakan langsung kepada rakyat apakah dibutuhkan perubahan UUD NRI 1945 melalui referendum untuk mendapatkan legitimasi sosial dan legitimasi politik dari rakyat. Sebagai bangsa yang sudah mulai mapan dalam kehidupan demokrasi maka jalan referendum dapat dilakukan bangsa ini untuk menentukan keberlangsungan dan keberlanjutan kehidupan berbangsa dan bernegara. Kita dapat mencontoh inggris yang baru saja melakukan referendum meminta pendapat rakyat untuk keluar dari Uni Eropa (Brexit) pada tahun 2016 ini. Setelah dilakukan referendum maka selanjutnya MPR yang memproses untuk melakukan perubahan UUD NRI 1945.

Mengenai ketentuan pasal 37 ayat (2) bahwa setiap usul perubahan pasalpasal UndangUndang Dasar diajukan secara tertulis dan ditunjukkan dengan jelas bagian yang diusulkan untuk diubah beserta alasannya. Maka untuk menjamin kredibilitas dan kualitas perubahan UUD NRI 1945 perlu dipersiapkan naskah akademik sebagaimana dalam proses persiapan pembentukan undang-undang sebagaimana diatur dalam UU Nomor 11 
"Muh. Risnain dan "Sri Karyati|Menimbang Gagasan Perubahan Konstitusi Dan Tata Cara.......

tahun 2012 tentang pembentukan peraturan perundang-undangan.

Mengenai ketentuan pasal 105 peraturan tata tertib MPR mengenai jumlah pengusul dan pasal yang diusulkan untuk diubah. Menurut hemat penulis pimpinan MPR hanya memeriksa persyaratan administratif saja tidak memiliki kewenangan menilai substansi usul perubahan secara substantif. Alasannya, pertama, usulan perubahan adalah hak konstitusional anggota DPR yang sangat penting bagi jalannya demokrasi, jika usulan perubahan UUD NRI 1945 dinilai secara substansi oleh pimpinan MPR maka dapat saja MPR tidak menerima usulan itu karena alasan politis yang berbeda dengan pengusul. Kedua, pimpinan MPR adalah juru bicara anggota MPR (speaker) bukan atasan anggota MPR yang lain, maka usulan yang merupakan hak konstitusinal tidak boleh dinilai oleh pimpinan MPR tetapi dibiarkan untuk dibahas oleh panitia khusus yang dibentuk untuk itu.

Terkait kewenangan panitia ad hoc dapat menyempurnakan/mengubah rumusan pasal yang diajukan oleh pihak pengusul. Menurut penulis tidak tepat jika panitia ad hoc dapat menyempurnakan/mengubah rumusan pasal yang diajukan oleh pihak pengusul karena dapat mendistorsi keinginan pengusul dan dapat mengurangi hak konstitusional pengusul. Oleh karena itu menurut penulis pembahasan usulan pengusul dapat dilakukan dalam sidang yang dilakukan oleh pansus yang dibentuk oleh MPR.

\section{SIMPULAN}

Terdapat beberapa simpulan yang dapat diambil dalam makalah ini, pertama, gagasan perubahan UUD NRI 1945 merupakan gagasan yang konstitusional, akademis, sesuai dengan pengalaman sejarah yang berkembang sesuai dengan perkembangan kehidupan masyarakat. Gagasan itu akan dapat terwujud manakala didahului oleh situasi sosial dan politik yang mendukungnya. Kedua, gagasan untuk repositioning MPR sebagai lembaga tertinggi negara menghadapi hambatan konstitusional karena perubahan sistem pemilihan presiden dari pemilihan oleh MPR menjadi pemilihan langsung oleh rakyat, ketiga, beberapa usulan substansi perubahan UUD berkaitan dengan, wilayah negara pasal (25 A), komisi negara (pasal 30) dan pasal 33 (hak penguasaan negara), dan, mekanisme perubahan dilakukan melalui referendum terlebih dahulu yang diikuti oleh proses konstitusional di MPR.

Rekomendasi tulisan ini adalah, perubahan UUD NRI 1945 adalah sebuah keniscayaan karena konstitusi adalah dokumen yang dibuat manusia bukan kitab suci yang berasal dari Tuhan. Maka untuk perubahan itu penulis perlu menyarankan kepada badan pengkaji DPR untuk terus menggalakan kajian akademis terkait hal ini dengan cara mengkaji setiap pasal dalamUUD NRI 1945.

\section{DAFTAR PUSTAKA}

Jimly Asshiddiqie, Pengantar Ilmu Hukum Tata Negara, (Jakarta : Sekjen MK RI,2006).

, Perihal Undang-Undang, (Jakarta : Konstitusi Press, 2006).

Lili Rasjidi dan I.B.Wyasa Putra, Hukum Sebagai Suatu Sistem, (Bandung, Mandar Maju : 2003).

Maria Farida S, Ilmu Perundang-undangan : Jenis, Fungsi dan Materi Muatan,(Yogyakarta : Kanisius, 2007).

Mochtar Kusumaatmadja, Konsep-Konsep Hukum dalam Pembangunan : Kumpulan Karya Tulis Prof. Dr. Mochtar Kusumaatmadja, SH.,LL.M (Bandung: Alumni, 2002).

Moh.Mahfud M.D, Membangun Politik Hukum, Menegakkan Konstitusi ( 
Jakarta : Pustaka LP3ES , 2006).

Ni,matul Huda, Politik ketatanegaraan Indonesia : kajian terhadap dinamika perubahan UUD 1945, (Yogyakarta : FH UII, 2002,).

Pusat Studi Hukum dan Kebijakan, Legislasi : Aspirasi atau Transaksi : Catatan Kinerja DPR 2011, (Jakarta :PSHK, 2012).

Rachmad Maulana Firmansyah, et, al, Catatan Kinerja DPR 2012: Fondasi Tahun Politik (Jakarta : PSHK, 2013), hlm.

Saldi Isra, Kekuasaan dan Perilaku Korupsi : catatan Hukum, (Jakarta : Kompas Media Nusantara, 2009).

Satjipto Rahardjo, Ilmu Hukum, (Bandung : Citra Aditya, 2000).

Soetandyo Wignjosoebroto, Hukum : Konsep dan Metode, (Malang : Setara Press, 2013).

Sudikno Mertokusumo, Penemuan Hukum : Sebuah Pengantar (Jogjakarta : Liberty, 2003). 